\title{
Coexistence of adenomyosis uteri and endometrial cancer is associated with an improved prognosis compared with endometrial cancer only
}

\author{
LINDA HERTLEIN, JOHANNA RATH, CHRISTINE ZEDER-GÖSS, SOPHIE FÜRST, DANIELA BAYER, \\ FABIAN TRILLSCH, SVEN MAHNER, ALEXANDER BURGES and UDO JESCHKE
}

Department of Obstetrics and Gynecology, Ludwig-Maximilian University of Munich, D-81377 Munich, Germany

Received January 24, 2017; Accepted May 11, 2017

DOI: $10.3892 / 01.2017 .6592$

\begin{abstract}
The present study aimed to identify differences in protein expression in cases of endometrioid endometrial cancer (EEC) with and without coexisting adenomyosis uteri (AM), and to evaluate the histopathological and prognostic distinctions. The total cohort included 22 patients in Group A (patients with concomitant AM and EEC) and 35 patients in Group B (patients affected only by EEC). Evaluation of the following factors was performed: Tumour grade, International Federation of Gynaecology and Obstetrics (FIGO) stage, survival, and expression of estrogen receptor $\beta(E R \beta)$, glycodelin and inhibin $\beta$ B. Group A (AM and EEC) was associated with a lower tumour grade (G1, 90.9 vs. $45.7 \%$; $\mathrm{P}=0.001)$ and a lower FIGO stage (FIGO stage I, 100 vs. 80\%; P=0.002) compared with Group B (EEC only). In the survival analysis, Group A was associated with a significantly higher 5-year survival rate (95 vs. 82\%; $\mathrm{P}=0.024$ ) than Group B. In addition, the expression of ER $\beta$ in Group A was significantly higher $(\mathrm{P}<0.001)$, whereas the expression of glycodelin is significantly lower $(\mathrm{P}=0.028)$, compared with Group B. The results of the present study indicate that the presence of AM in cases of EEC may be a positive prognostic factor.
\end{abstract}

\section{Introduction}

Endometrial cancer (EC) is the most commonly occurring malignant neoplasm of the female reproductive tract in

Correspondence to: Dr Linda Hertlein, Department of Obstetrics and Gynecology, Ludwig-Maximilian University of Munich, Campus Großhadern, Marchioninistraße 15, D-81377 Munich, Germany

E-mail: linda.hertlein@med.uni-muenchen.de

Abbreviations: AM, adenomyosis uteri; EC, endometrial cancer; EEC, endometrioid endometrial cancer; ER $\beta$, estrogen receptor $\beta$; IRS, immunoreactivity score

Key words: endometrioid endometrial cancer, adenomyosis uteri, estrogen receptor $\beta$, glycodelin, inhibin $\beta \mathrm{B}$ developed countries (1). Typically, EC is confined to the uterus and is characterized by a good prognosis, with an overall 5 -year survival rate of $75-80 \%$ (2). Endometrial endometrioid cancer (EEC), a histological subtype of EC, represents $80 \%$ of all cases of EC (2).

Adenomyosis uteri (AM) is defined by the presence of endometrial mucosa within the myometrium. In hysterectomy specimens obtained during the treatment of EEC, AM may be found in $16-42 \%$ (3-6). A more favorable prognosis and a lower histopathological grade in cases EEC with coexisting AM has been reported in a number of studies $(3,4,7,8)$. However the significance of the presence of AM in cases of EEC remains unclear. Despite early predictions, the collective evidence suggests that estrogen receptor $\beta$ (ER $\beta)$ serves an important role in normal endometrial tissue (9-11) and also in most, if not all, benign and malignant endometrial diseases (12-14). In ectopic endometrial lesions and $\mathrm{AM}$, it has been reported that high levels of ER $\beta$ expression, 100-times higher than that in eutopic endometrium, may be detected (15). In EEC, it has been reported that ER $\beta$ mRNA and protein levels are decreased compared with adjacent normal endometrium or normal proliferative endometrium from healthy premenopausal women $(16,17)$. However, a potential oncogenic role of $\mathrm{ER} \beta$ has also been proposed in other reports, which showed an upregulation of the ER $\beta 5$ transcript in high-grade $\operatorname{EEC}(18,19)$. In summary, ER $\beta$ appears to play a dual role: As a tumour suppressor in healthy endometrium, and as a potential tumour promoter in high-grade EC cells that have lost other receptor subtypes (12).

The present study aimed to identify the differences in the expression of several proteins, including ER $\beta$, in cases of EEC with and without AM, and to evaluate the potential histopathological and prognostic distinctions between these two groups.

\section{Patients and methods}

Patients and specimen characteristics. The present retrospective observational cohort study included 57 patients with EEC, whose records were obtained from the archives of the Department of Obstetrics and Gynaecology, Ludwig-Maximilian University of Munich (Munich, Germany). Group A consisted of 22 patients with coexistent EEC and AM. 
Table I. Primary antibodies used in the study.

\begin{tabular}{|c|c|c|c|c|c|}
\hline $\begin{array}{l}\text { Primary } \\
\text { antibody }\end{array}$ & Host & Clone & Cat. no. & Supplier & Dilution \\
\hline $\begin{array}{l}\text { Estrogen } \\
\text { receptor } \beta 1\end{array}$ & Mouse (IgG2a) & PPG5/10 & M7292 & $\begin{array}{l}\text { Dako; Agilent Technologies } \\
\text { GmbH, Waldbronn, Germany }\end{array}$ & $\begin{array}{l}\text { 1:200 in Dako } \\
\text { antibody diluent }\end{array}$ \\
\hline Glycodelin & 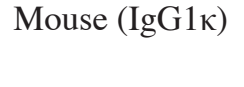 & $6 \mathrm{~F} 2$ & $116-0646$ & $\begin{array}{l}\text { Zytomed Systems GmbH, } \\
\text { Berlin, Germany }\end{array}$ & $1: 4,000$ in PBS \\
\hline Inhibin $\beta B$ & Mouse (IgG2a) & $\mathrm{C} 5$ & MCA1661 & $\begin{array}{l}\text { Serotec; Bio-Rad Laboratories, } \\
\text { Inc., Hercules, CA, USA }\end{array}$ & $\begin{array}{l}1: 70 \text { in Dako } \\
\text { antibody diluent }\end{array}$ \\
\hline
\end{tabular}

Group B comprised 35 patients with EEC alone. Patients had undergone surgical resection of EEC between January 1990 and December 2002. The patients' former tumour stages were corrected to the updated FIGO classification from 2010 (20).

Study design. Patients were recruited between 1990 and 2002 as described; follow-up continued until December 2015. Clinical and follow-up data were retrieved retrospectively from patient charts and from the Munich Cancer Registry (Munich, Germany). The overall mean follow-up time of the cohort was 8 years (range, 4-15 years). The outcomes assessed were overall survival time and progression free survival. Overall survival is defined as the number of months between the patient's initial diagnosis with endometrial carcinoma until the last follow up or mortality. Progression free survival is defined by the number of months between the initial diagnosis and when the patient developed either a relapse or further progression of the disease, including lymph node involvement or metastasis.

Ethical approval. All patient data were fully anonymized, and the study was performed according to the standards set in the Declaration of Helsinki, 1975. All tumour tissue used in the study was leftover material that had initially been collected for histopathological diagnostic assessments. All diagnostic procedures had already been fully completed when samples were retrieved for the study. The present study was approved by the Ethics Committee of the Ludwig-Maximilian University of Munich (approval no. 449-14). Investigators were blinded to the patients' clinical information during experimental analysis.

Assay methods. Formalin-fixed, paraffin-embedded tissue sections were stored at room temperature. Tumour tissues and tissues with AM were selected from hematoxylin-stained whole uterus slides. Sections with a thickness of $2 \mu \mathrm{m}$ of tumour or AM positive tissue were prepared and used for the staining. Slides were dewaxed in xylol and rehydrated in a descending series of alcohol concentrations. The immunohistochemical staining of the paraffin-embedded tissues for glycodelin (in Group B) and inhibin $\beta$ B was detected with the avidin-biotin complex method described by Kricka and Wild (21) using the mouse VECTASTAIN Elite ABC kit (Vector Laboratories, Inc., Burlingame, CA, USA). For the detection of glycodelin (in Group A) and ER $\beta 1$, the ZytoChem Plus HRP Polymer kit (Zytomed Systems GmbH, Berlin, Germany) was used, according to the manufacturer's protocol. The primary antibodies are described in Table I, and were incubated with the tissue sections for $16 \mathrm{~h}$ at $4^{\circ} \mathrm{C}$, prior to detection with the aforementioned methods.

Immunoreactivity was quantified with Remmele's semi-quantitative immunoreactivity score (IRS) (22) by two independent observers by consensus. This scoring method quantifies immunoreactivity by multiplication of the optical staining intensity score $(0$, none; 1 , weak; 2 , moderate; or 3 , strong) with a score representing the percentage of positively stained cells ( 0 , no staining; $1, \leq 10 \%$ of cells; $2,11-50 \%$ of cells; $3,51-80 \%$ of cells; or $4, \geq 81 \%$ of cells), resulting in the overall IRS, which can be subdivided as follows: 0-2, negative; 3-4, weak-positive; 6-8, moderate-positive; and 9-12, strong-positive.

Statistical analysis. The IBM statistical package SPSS (version 23; IBM, Armonk, NY, USA) was used to test data for statistical significance. A Mann-Whitney U-Test was performed for analyses of differences in staining results and Spearman's rank correlation analysis was performed for correlation analyses. Survival times were compared by using Kaplan-Meier estimates, and the differences in the patients' overall survival rates were tested for significance by using the log-rank test. Data were considered to be statistically significantly different where $\mathrm{P}<0.05$.

\section{Results}

General patient features. The patients in Group A (AM and EEC) and Group B (EEC only) were similar in age at time of EEC diagnosis (mean age, 63.9 vs. 63.2 years, respectively). With regard to the prevalence of diabetes, hypertension or obesity in the patients' medical histories, there were no significance differences between the groups. The clinicopathological characteristics and follow-up data of all included patients are reported in detail in Table II.

AM is associated with lower FIGO stage in EEC. In the current cohort, the surgical FIGO stage differed significantly between the two groups. In Group A (AM and EEC), $22 / 22$ patients $(100 \%)$ were assigned to FIGO stage I, compared with 28/35 patients $(80 \%)$ in Group B (EEC only; $\mathrm{P}=0.002)$. Notably, $86.4 \%$ (19/22 patients) of Group A and $51.4 \%$ (18/35 patients) of Group B were categorized as stage IA. In Group B, 3/35 patients (8.6\%) were assigned to 
Table II. General features, histological features and follow-up data of the patients in the two study groups.

\begin{tabular}{|c|c|c|c|c|}
\hline Characteristic & All patients $(n=57)$ & Group $A^{a}(n=22)$ & Group $B^{b}(n=35)$ & P-value \\
\hline Age at diagnosis, years & & & & 0.987 \\
\hline Mean & 63.5 & 63.9 & 63.2 & \\
\hline Range & $36-83$ & $52-82$ & $36-83$ & \\
\hline Obesity, n (\%) & & & & 0.583 \\
\hline Yes & $18(31.6)$ & $6(27.3)$ & $12(34.3)$ & \\
\hline No & $39(68.4)$ & $16(72.7)$ & $23(65.7)$ & \\
\hline Diabetes, n (\%) & & & & 0.946 \\
\hline Yes & $8(14.0)$ & $3(13.6)$ & $5(14.3)$ & \\
\hline No & $49(86.0)$ & $19(86.4)$ & $30(85.7)$ & \\
\hline Hypertension, n (\%) & & & & 0.703 \\
\hline Yes & $19(33.3)$ & $8(36.4)$ & $11(31.4)$ & \\
\hline No & $38(66.7)$ & $14(63.6)$ & $24(68.6)$ & \\
\hline FIGO stage, n (\%) & & & & 0.002 \\
\hline I & $50(87.7)$ & $22(100)$ & $28(80.0)$ & \\
\hline IA & $37(64.9)$ & $19(86.4)$ & $18(51.4)$ & \\
\hline IB & $13(22.8)$ & $3(13.6)$ & $10(28.6)$ & \\
\hline II & $3(5.3)$ & $0(0.0)$ & $3(8.6)$ & \\
\hline III & $4(7.0)$ & $0(0.0)$ & $4(11.4)$ & \\
\hline IV & $0(0.0)$ & $0(0.0)$ & $0(0.0)$ & \\
\hline Lymph node metastasis, n (\%) & $2(3.5)$ & $1(4.5)$ & $1(2.9)$ & \\
\hline Distant metastasis, $\mathrm{n}(\%)$ & $0(0.0)$ & $0(0.0)$ & $0(0.0)$ & \\
\hline Grade, $\mathrm{n}(\%)$ & & & & 0.001 \\
\hline 1 & $36(63.2)$ & $20(90.9)$ & $16(45.7)$ & \\
\hline 2 & $19(33.3)$ & $1(4.5)$ & $18(51.4)$ & \\
\hline 3 & $1(1.8)$ & $0(0.0)$ & $1(2.9)$ & \\
\hline Lymphatic invasion, n (\%) & & & & 0.849 \\
\hline Yes & $3(5.3)$ & $1(4.5)$ & $2(5.7)$ & \\
\hline No & $54(94.7)$ & $21(95.5)$ & $33(94.3)$ & \\
\hline Vascular invasion, $\mathrm{n}(\%)$ & & & & 0.428 \\
\hline Yes & $1(1.8)$ & $0(0.0)$ & $1(2.9)$ & \\
\hline No & $56(98.2)$ & $22(100)$ & $34(97.1)$ & \\
\hline \multicolumn{5}{|l|}{ Follow-up duration, years } \\
\hline Mean & - & 8.9 & 7.8 & \\
\hline Range & - & $4-14$ & $5-14$ & \\
\hline Mortality during follow-up, n (\%) & $10(17.5)$ & $2(9.1)$ & $8(22.9)$ & \\
\hline No follow-up, n (\%) & $2(5.7)$ & $0(0.0)$ & $2(5.7)$ & \\
\hline
\end{tabular}

${ }^{\mathrm{a}} \mathrm{AM}$ and EEC; ${ }^{\mathrm{b}} \mathrm{EEC}$ only. AM, adenomyosis uteri; EEC, endometrioid endometrial cancer; FIGO, International Federation of Gynaecology and Obstetrics.

FIGO stage II, and 4/35 patients $(11.4 \%)$ were assigned to FIGO stage III.

AM is associated with a lower grade in EEC. With regard to the prevalence of lymphatic or vascular invasion, no significant differences between the two groups could be identified. Regarding tumour grade, a significant difference was identified between Group A and Group B (G1, 90.9 vs. 45.7\%; G2, 4.5 vs. $51.4 \%$; G3, 0 vs. $2.9 \%$, respectively; $\mathrm{P}=0.001$; Fig. 1 ). Thus, higher tumour grades, indicating poor differentiation of the tumour cells, were more common in the patients without AM.

AM is associated with increased survival time in patients with EEC. The survival curves of the patients in Groups A and $\mathrm{B}$ are shown in Fig. 2. The 5-year overall survival rate of Group A was $95 \%$, which was significantly higher than that of Group B ( $82 \%$; $\mathrm{P}=0.024)$. The survival rate after 10 years remained the same for Group $\mathrm{A}$, whereas the 10-year survival rate of Group B decreased to $72 \%$. The mean overall survival 
Table III. Expression of the different proteins in the different groups.

\begin{tabular}{lcccr}
\hline Protein & All patients & Group A & Group B & P-value \\
\hline Estrogen receptor $\beta$ (IRS >2), n (\%) & & & & $<0.001$ \\
Yes & $7(12.7)$ & $6(30.0)$ & $1(2.9)$ & \\
No & $48(87.3)$ & $14(70.0)$ & $34(97.1)$ & 0.028 \\
Glycodelin (IRS >2), n (\%) & $38(86.4)$ & $15(78.9)$ & $23(92.0)$ & \\
Yes & $6(13.6)$ & $4(21.1)$ & $2(8.0)$ & 0.077 \\
No & & & & \\
Inhibin $\beta$ B (IRS >2), n (\%) & $34(94.4)$ & $14(93.3)$ & $20(95.2)$ & $1(4.8)$ \\
Yes & $2(5.5)$ & $1(6.7)$ & & \\
No & & & & \\
\hline
\end{tabular}

${ }^{\mathrm{a}} \mathrm{AM}$ and EEC; ${ }^{\mathrm{b} E E C}$ only. AM, adenomyosis uteri; EEC, endometrioid endometrial cancer; IRS, immunoreactivity score.

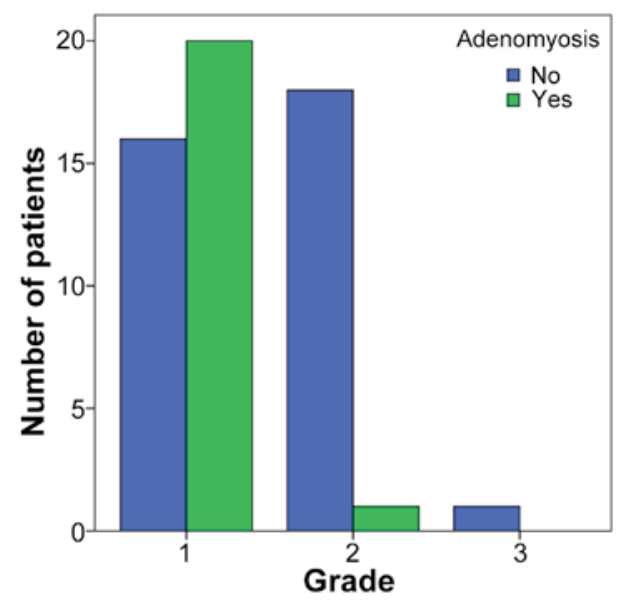

Figure 1. Association between grade and presence of adenomyosis uteri in patients with endometrioid endometrial cancer.

time was higher in Group A than in Group B (159 months (13.25 years) vs. 142 months (11.8 years), respectively). In summary, patients with AM and EEC (Group A) had a significantly increased mean overall survival times than patients with EEC alone (Group B; P=0.024).

AM is associated with increased expression of ER $\beta$ and decreased expression of glycodelin in EEC. Table III summarizes the results of the different protein expression analyses. When comparing the percentage of cases with an IRS $>2$ for ER $\beta$, a significant difference was identified between the two groups $(\mathrm{P}<0.001)$ : In Group $\mathrm{B}, \mathrm{ER} \beta$ expression was detected in $6 / 35$ cases $(17.1 \%)$, and only 1 case $(2.9 \%)$ was assigned an IRS >2 (Fig. 3); whereas, in Group A, 14/20 cases assessed for ER $\beta$ expression (70\%) exhibited expression of ER $\beta$, with 6 cases $(30 \%)$ assigned an IRS $>2$ (Fig. 4). Therefore, the presence of AM in cases of EEC is associated with higher expression of ER $\beta$ than that in cases of EEC alone. In Group A, the prevalence of glycodelin expression with an IRS $>2$ was significantly lower $(\mathrm{P}=0.028$; Fig. 5) than that in Group B (Fig. 6; Table III). With regard to the prevalence of inhibin $\beta \mathrm{B}$ expression (data not shown), no significant differences between the two groups were identified $(\mathrm{P}=0.077)$.

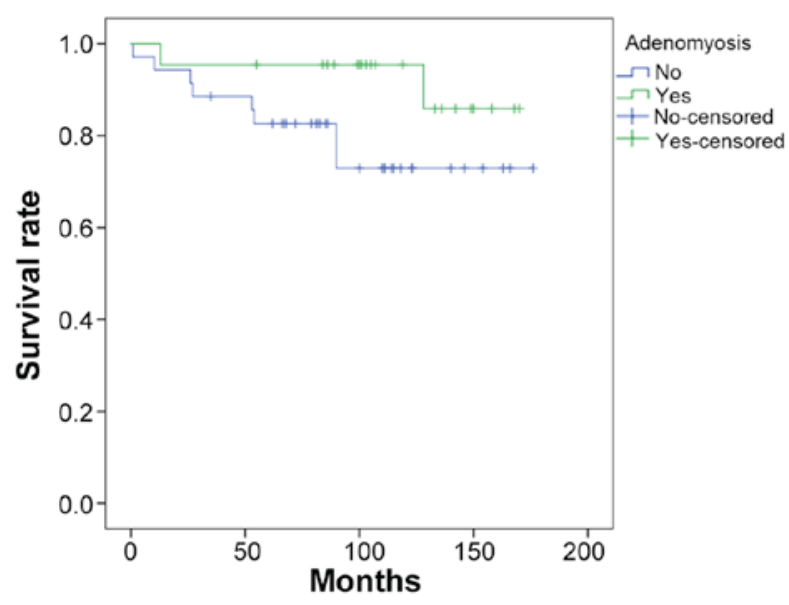

Figure 2. Survival curves of the endometrioid endometrial cancer patients with and without adenomyosis uteri $(\mathrm{P}=0.024)$.

\section{Discussion}

The majority of cases of EC (80\%) are of the endometrioid subtype (EEC) (2). This Type I EC is estrogen-dependent, is typically well-differentiated, and is characterized by a good prognosis in general. By contrast, Type II EC is estrogen-independent, predominantly comprises the serous and clear cell histological subtypes, and has a worse prognosis (23-26).

$\mathrm{AM}$ is a benign disease characterized by the presence of endometrial mucosa within the myometrium. It is a hormone-dependent disease and typically regresses subsequent to menopause. In postmenopausal women with EEC, there is a higher prevalence of AM and myoma uteri than in patients of the same age with uterine prolapse (27). Certain studies have reported a more favorable prognosis and a lower histopathological grade in cases of EEC with coexisting AM $(3,4,7,8)$.

Regarding the tumour stage, all 22 patients in Group A (AM and EEC; 100\%) vs. only 28/35 patients (80\%) in Group B (EEC only) were assigned to FIGO stage I $(\mathrm{P}=0.02)$. Additionally, a higher percentage of patients in Group A, compared with Group B, were assigned to FIGO stage IA ( 86.4 vs. $51.4 \%$ ). These findings are in accord with the findings of studies by Musa et al (28) and Gizzo et al (7), which 


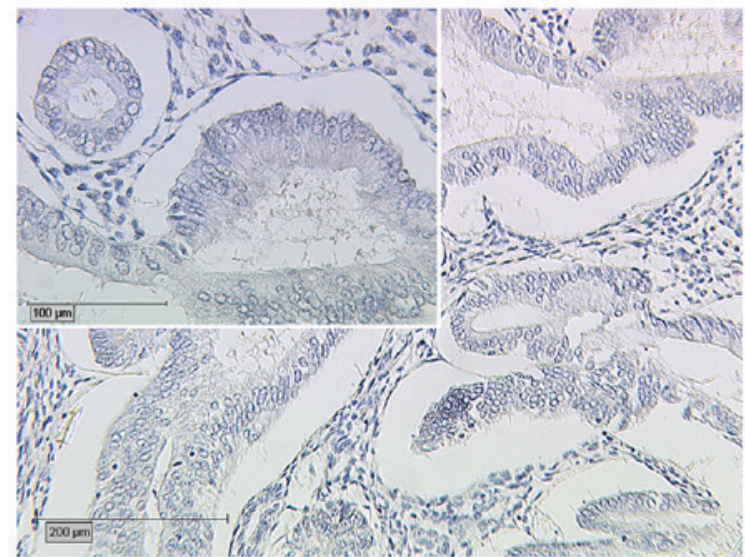

Figure 3.ER $\beta$ expression in Group B (patients with endometrioid endometrial cancer only). Representative photomicrographs of ER $\beta$ immunohistochemical staining are shown (immunoreactivity score, 0 ). ER $\beta$, estrogen receptor $\beta$.

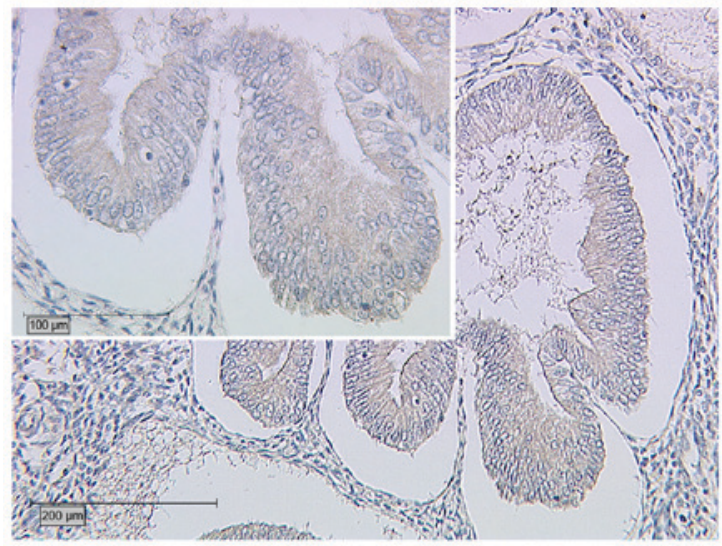

Figure 5. Glycodelin expression in Group A (patients with endometrioid endometrial cancer and adenomyosis uteri). Representative microphotographs of glycodelin immunohistochemical staining are shown (immunoreactivity score, 4).

reported that concurrent $\mathrm{AM}$ and EEC was associated with a lower tumour grade, with $<50 \%$ myometrial invasion, and with the absence of lymphovascular space involvement and lymph node metastasis. Furthermore, the lower histopathological grade (G1, 90.9 vs. $45.7 \%$, respectively) in Group A (with AM) vs. Group B (without AM) observed in the present study was consistent with the report by Koshiyama et al (8). Thus, the present study confirmed that patients with coexisting AM and EEC tend to have a lower tumour stage and a higher differentiation grade. One possible explanation for this finding could be that there is an adhesion mechanism between AM foci and cancer cells; these adhesions may prevent cancer cells from invading deeper in the myometrium (29-31). Regarding the survival data, patients with EEC and coexistent AM showed significantly more favorable outcomes than those with EEC alone.

Although previous studies have investigated ER $\beta$, glycodelin and inhibin $\beta B$ in cases of AM and EEC (31-35), to the best of our knowledge, the present study is the first in which these factors were measured and compared with one other in a single study. Regarding the expression of ER $\beta$, Group A (AM and EEC) showed a significantly increased

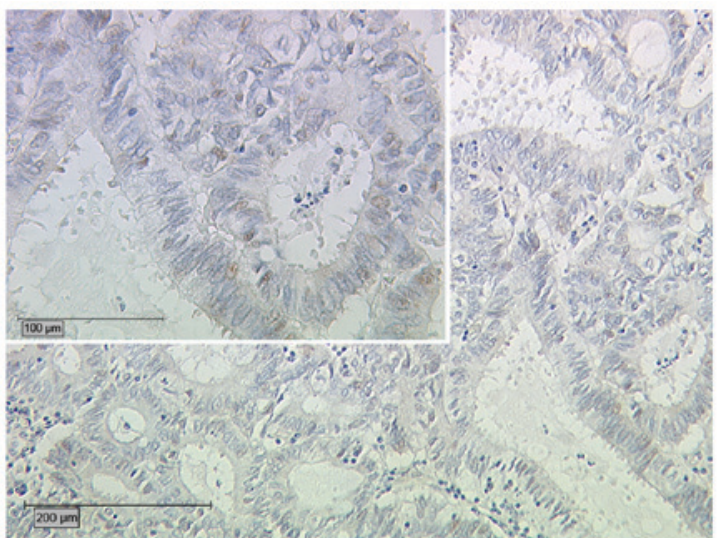

Figure 4. ER $\beta$ expression in Group A (patients with endometrioid endometrial cancer and adenomyosis uteri). Representative microphotographs of ER $\beta$ immunohistochemical staining are shown (immunoreactivity score, 2). ER $\beta$, estrogen receptor $\beta$.

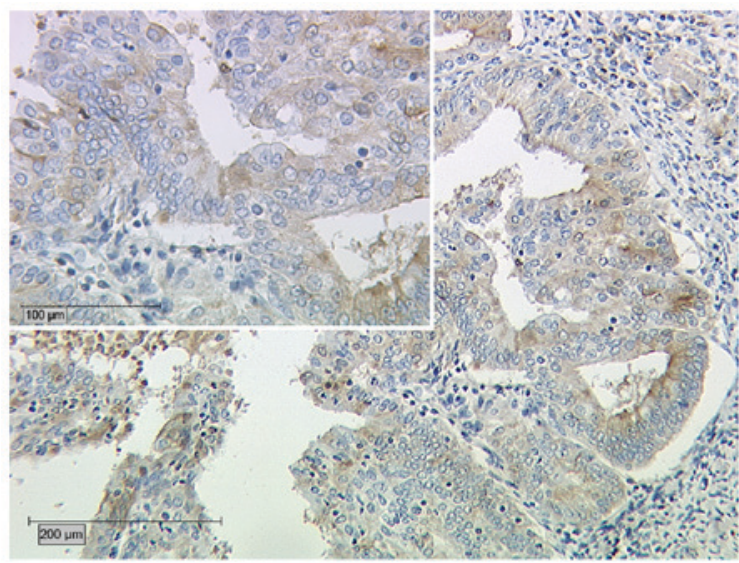

Figure 6. Glycodelin expression in Group B (patients with endometrioid endometrial cancer only). Representative microphotographs of glycodelin immunohistochemical staining are shown (immunoreactivity score, 6).

prevalence compared with Group B (EEC). This result may be explained by the increased expression of ER $\beta$ that has been shown to be present in AM (15). The decreased expression of ER $\beta$ in patients with EEC alone was also consistent with previous studies $(16,17)$.

Glycodelin, also known as a progestogen-associated endometrial protein, is a glycoprotein that has immunosuppressive capacity, and is predominantly produced in reproductive tissues (36). In a former study by our group, intermediate and high expression levels of glycodelin were associated with a prolonged survival time in patients with EC (33). Notably, in the current study, the prevalence of glycodelin expression in Group A (AM and EEC) was significantly decreased compared with that in Group B (EEC; $\mathrm{P}=0.028)$. This can be explained because women with endometriosis exhibited a $>50$-fold downregulation of glycodelin in endometrial tissue compared to normal controls during the window of implantation (37). This decreased glycodelin expression also seemed to persist during the carcinogenesis of EC in the present study. In this context, women with AM and EEC appear to have a survival advantage, which could be explained by the angiogenic role of glycodelin during tumorigenesis; Song et al (38) 
found that a synthetic peptide derived from the sequence of glycodelin may serve an important role in neovascularization during embryogenesis and tumour development. It is notable that the inverse association between the presence of AM and the expression of glycodelin in EEC has only been identified in specimens that were stained with an antibody raised against a peptide sequence of glycodelin, and not in those that were stained with anti-glycodelin A antibody, which is specific to a particular glycosylated form of glycodelin (39-41). The measurement of glycodelin or ER $\beta$ was previously described in endometrial tissue $(42,43)$. However, no correlation between these two parameters has been described.

Inhibins are heterodimers consisting of an $\alpha$ subunit and a $\beta$ subunit, and they belong to the transforming growth factor $\beta$ cytokine family (44). The $\alpha$ subunit can dimerize with either $\beta A$ or $\beta B$ to form inhibin $A(\alpha-\beta A)$ or $B(\alpha-\beta B)(45,46)$. In a previous study by our group, hyperplastic endometrial tissue was found to exhibit more intense staining for inhibins, particularly inhibin $\beta \mathrm{A}$ and $\beta \mathrm{B}$, compared with $\mathrm{EC}$. The presence of inhibin $\beta \mathrm{A}$ and $\beta \mathrm{B}$ suggests that they have an important function in endometrial pathogenesis and in endometrial carcinogenesis (34). For inhibin $\beta \mathrm{B}$, more intense labelling was noted in atypical hyperplasia compared with EC (34). Thus, the present study investigated the differences in the expression of inhibin $\beta \mathrm{B}$ between the two groups. However, no significant differences were observed. In adenosquamous EC, the absence of the expression of inhibin $\beta B$ and $\operatorname{ER} \beta$ indicates the malignancy of these tumors (32).

One limitation of the present study was the variation in immunostaining in each specimen due to varying expression levels in different regions of the tumour. Other molecular methods for determining expression levels, such as western blotting, would be desirable to verify the results. However, as the present study utilized formalin-fixed, paraffin-embedded tissue specimens, this was not possible.

In conclusion, in cases of EEC, the presence of AM is associated with a lower FIGO stage, lower tumour grade and an increased survival rate. The expression of ER $\beta$ was more prevalent in cases of AM and EEC than in cases of EEC alone, whereas glycodelin expression was less prevalent when AM was present. Future research should focus on the influence of estrogen on the AM and EEC cases, and on prevention strategies in the development of EEC.

\section{Acknowledgements}

The authors would like to thank Ms. Christina Kuhn, Ms. Sandra Schulze and Ms. Simone Hofmann from the Ludwig-Maximilian University of Munich for their technical support. In addition, the authors thank Mr. Laurent Soussana from the Ludwig-Maximilian University of Munich for language revision.

\section{References}

1. Siegel RL, Miller KD and Jemal A: Cancer statistics, 2016. CA Cancer J Clin 66: 7-30, 2016.

2. Prat J: Prognostic parameters of endometrial carcinoma. Hum Pathol 35: 649-662, 2004.

3. Bergeron C, Amant F and Ferenczy A: Pathology and physiopathology of adenomyosis. Best Pract Res Clin Obstet Gynaecol 20: 511-521, 2006.
4. Kucera E, Hejda V, Dankovcik R, Valha P, Dudas M and Feyereisl J: Malignant changes in adenomyosis in patients with endometrioid adenocarcinoma. Eur J Gynaecol Oncol 32: 182-184, 2011.

5. Ismiil N, Rasty G, Ghorab Z, Nofech-Mozes S, Bernardini M, Ackerman I, Thomas G, Covens A and Khalifa MA: Adenomyosis involved by endometrial adenocarcinoma is a significant risk factor for deep myometrial invasion. Ann Diagn Pathol 11: 252-257, 2007.

6. Seidman JD and Kjerulff KH: Pathologic findings from the Maryland Women's Health Study: Practice patterns in the diagnosis of adenomyosis. Int J Gynecol Pathol 15: 217-221, 1996

7. Gizzo S, Patrelli TS, Dall'Asta A, DI Gangi S, Giordano G, Migliavacca C, Monica M, Merisio C, Nardelli GB, Quaranta M, et al: Coexistence of adenomyosis and endometrioid endometrial cancer: Role in surgical guidance and prognosis estimation. Oncol Lett 11: 1213-1219, 2016.

8. Koshiyama M, Okamoto $\mathrm{T}$ and Ueta M: The relationship between endometrial carcinoma and coexistent adenomyosis uteri, endometriosis externa and myoma uteri. Cancer Detect Prev 28: 94-98, 2004.

9. Mylonas I, Jeschke U, Shabani N, Kuhn C, Kriegel S, Kupka MS and Friese K: Normal and malignant human endometrium express immunohistochemically estrogen receptor alpha (ER-alpha), estrogen receptor beta (ER-beta) and progesterone receptor (PR). Anticancer Res 25: 1679-1686, 2005.

10. Mylonas I, Jeschke U, Shabani N, Kuhn C, Balle A, Kriegel S, Kupka MS and Friese K: Immunohistochemical analysis of estrogen receptor alpha, estrogen receptor beta and progesterone receptor in normal human endometrium. Acta Histochem 106: 245-252, 2004.

11. Brandenberger AW, Lebovic DI, Tee MK, Ryan IP, Tseng JF, Jaffe RB and Taylor RN: Oestrogen receptor (ER)-alpha and ER-beta isoforms in normal endometrial and endometriosis-derived stromal cells. Mol Hum Reprod 5: 651-655, 1999.

12. Hapangama DK, Kamal AM and Bulmer JN: Estrogen receptor $\beta$ : The guardian of the endometrium. Hum Reprod Update 21: 174-193, 2015.

13. Mylonas I, Speer R, Makovitzky J, Richter DU, Briese V, Jeschke U and Friese K: Immunohistochemical analysis of steroid receptors and glycodelin A (PP14) in isolated glandular epithelial cells of normal human endometrium. Histochem Cell Biol 114: 405-411, 2000.

14. Shabani N, Kuhn C, Kunze S, Schulze S, Mayr D, Dian D, Gingelmaier A, Schindlbeck C, Willgeroth F, Sommer H, Jeschke U, et al: Prognostic significance of oestrogen receptor alpha (ERalpha) and beta (ERbeta), progesterone receptor A (PR-A) and B (PR-B) in endometrial carcinomas. Eur J Cancer 43: 2434-2444, 2007.

15. Bulun SE, Monsavais D, Pavone ME, Dyson M, Xue Q, Attar E, Tokunaga $\mathrm{H}$ and $\mathrm{Su}$ EJ: Role of estrogen receptor- $\beta$ in endometriosis. Semin Reprod Med 30: 39-45, 2012.

16. Paul M, Cholewa K, Mazurek U, Witek A and Wilczok T: Estrogen receptor beta delta 6 (ER beta delta 6 ) isoform in human endometrial hyperplasia and adenocarcinoma. Cancer Invest 22: 211-218, 2004.

17. Smuc T and Rizner TL: Aberrant pre-receptor regulation of estrogen and progesterone action in endometrial cancer. Mol Cell Endocrinol 301: 74-82, 2009.

18. Skrzypczak M, Bieche I, Szymczak S, Tozlu S, Lewandowski S, Girault I, Radwanska K, Szczylik C, Jakowicki JA, Lidereau R and Kaczmarek L: Evaluation of mRNA expression of estrogen receptor beta and its isoforms in human normal and neoplastic endometrium. Int J Cancer 110: 783-787, 2004.

19. Haring J, Schüler S, Lattrich C, Ortmann O and Treeck O: Role of estrogen receptor $\beta$ in gynecological cancer. Gynecol Oncol 127: 673-676, 2012.

20. Horn LC, Schierle K, Schmidt D, Ulrich U, Liebmann A and Wittekind C: Current TNM/FIGO classification for cervical and endometrial cancer as well as malignant mixed mullerian tumors. Facts and background. Pathologe 32: 239-243, 2011 (In German).

21. Kricka LJ and Wild D: Signal generation and detection systems (excluding homogeneous assays) In: The Immunoassay Handbook. 3rd edition. Amsterdam, Elsevier Publisher, pp220, 2005.

22. Remmele W and Stegner HE: Recommendation for uniform definition of an immunoreactive score (IRS) for immunohistochemical estrogen receptor detection (ER-ICA) in breast cancer tissue. Pathologe 8: 138-140, 1987 (In German). 
23. Tabernero JM, Alonso MC, Ojeda B, Fuentes J, Balart J, Badia J, Climent MA and Delgado E: Endometrial cancer stages I and II. Analysis of survival and prognostic factors. Eur J Gynaecol Oncol 16: 18-25, 1995.

24. Reisinger SA, Staros EB and Mohiuddin M: Survival and failure analysis in stage II endometrial cancer using the revised 1988 FIGO staging system. Int J Radiat Oncol Biol Phys 21: 1027-1032, 1991.

25. Ayhan A, Taskiran C, Celik C and Yuce K: The long-term survival of women with surgical stage II endometrioid type endometrial cancer. Gynecol Oncol 93: 9-13, 2004.

26. Mahdi H, Hou H, Kowk LL, Moslemi-Kebria M and Michener C: Type II endometrial cancer in Hispanic women: Tumor characteristics, treatment and survival compared to non-Hispanic white women. Gynecol Oncol 133: 512-517, 2014.

27. Koshiyama M, Morita Y, Fujii H, Kobashi Y and Yoshida M: Gynecologic malignancies accompanied by benign hormonedependent diseases. Menopause 8: 149-150, 2001.

28. Musa F, Frey MK, Im HB, Chekmareva M, Ellenson LH and Holcomb K: Does the presence of adenomyosis and lymphovascular space invasion affect lymph node status in patients with endometrioid adenocarcinoma of the endometrium? Am J Obstet Gynecol 207: 417.e1-e6, 2012.

29. Matsuo K, Cahoon SS, Gualtieri M, Scannell CA, Jung CE, Takano T, Paulson RJ, Muderspach LI and Roman LD: Significance of adenomyosis on tumor progression and survival outcome of endometrial cancer. Ann Surg Oncol 21: 4246-4255, 2014.

30. Matsuo K, Moeini A, Machida H, Scannell CA, Casabar JK, Kakuda M, Adachi S, Garcia-Sayre J, Ueda Y and Roman LD Tumor characteristics and survival outcome of endometrial cancer arising in adenomyosis: An exploratory analysis. Ann Surg Oncol 23: 959-967, 2016.

31. Mehasseb MK, Panchal R, Taylor AH, Brown L, Bell SC and Habiba M: Estrogen and progesterone receptor isoform distribution through the menstrual cycle in uteri with and without adenomyosis. Fertil Steril 95: 2228-2235, 2235.e1, 2011.

32. Gingelmaier A, Gutsche S, Mylonas I, Shabani N, Kuhn C Kunze S, Jeschke U and Friese K: Expression of HPV, steroid receptors (ERalpha, ERbeta, PR-A and PR-B) and inhibin/activin subunits (alpha, betaA and betaB) in adenosquamous endometrial carcinoma. Anticancer Res 27: 2011-2017, 2007.

33. Lenhard M, Heublein S, Kunert-Keil C, Vrekoussis T, Lomba I, Ditsch N, Mayr D, Friese K and Jeschke U: Immunosuppressive Glycodelin A is an independent marker for poor prognosis in endometrial cancer. BMC Cancer 13: 616, 2013.

34. Mylonas I, Makovitzky J, Hoeing A, Richter DU, Vogl J, Schulze S, Jeschke U, Briese V and Friese K: Inhibin/activin subunits beta-A (-betaA) and beta-B (-betaB) are differentially localised in normal, hyperplastic and malignant human endometrial tissue. Acta Histochem 108: 1-11, 2006.

35. Panoulis K, Christantoni E, Pliatsika P, Anagnostis P, Goulis DG, Kondi-Pafiti A, Armeni E, Augoulea A, Triantafyllou N Creatsa M and Lambrinoudaki I: Expression of gonadal steroid receptors in the ovaries of post-menopausal women with malignant or benign endometrial pathology: A pilot study. Gynecol Endocrinol 31: 613-617, 2015.
36. Mazurkiewicz JE, Bank JF and Joshi SG: Immunocytochemical localization of a progestagen-associated endometrial protein in the human decidua. J Clin Endocrinol Metab 52: 1006-1068, 1981.

37. Kao LC, Germeyer A, Tulac S, Lobo S, Yang JP, Taylor RN, Osteen K, Lessey BA and Giudice LC: Expression profiling of endometrium from women with endometriosis reveals candidate genes for disease-based implantation failure and infertility. Endocrinology 144: 2870-2881, 2003.

38. Song M, Ramaswamy S, Ramachandran S, Flowers LC, Horowitz IR, Rock JA and Parthasarathy S: Angiogenic role for glycodelin in tumorigenesis. Proc Natl Acad Sci U S A 98: 9265-9270, 2001.

39. Jeschke U, Kuhn C, Mylonas I, Schulze S, Friese K, Mayr D, Speer R, Briese V, Richter DU, Haase M and Karsten U: Development and characterization of monoclonal antibodies for the immunohistochemical detection of glycodelin A in decidual, endometrial and gynaecological tumour tissues. Histopathology 48: 394-406, 2006.

40. Jeschke U, Bischof A, Speer R, Briese V, Richter DU, Bergemann C, Mylonas I, Shabani N, Friese K and Karsten U: Development of monoclonal and polyclonal antibodies and an ELISA for the determination of glycodelin in human serum, amniotic fluid and cystic fluid of benign and malignant ovarian tumors. Anticancer Res 25: 1581-1589, 2005.

41. Jeschke U, Mylonas I, Kunert-Keil C, Stahn R, Scholz C, Janni W, Kuhn C, Schröder E, Mayr D and Friese K: Immunohistochemistry, glycosylation and immunosuppression of glycodelin in human ovarian cancer. Histochem Cell Biol 131: 283-295, 2009.

42. Fazleabas AT, Brudney A, Chai D, Langoi D and Bulun SE: Steroid receptor and aromatase expression in baboon endometriotic lesions. Fertil Steril 80 (Suppl 2): 820-827, 2003.

43. Fazleabas AT, Kim JJ, Srinivasan S, Donnelly KM, Brudney A and Jaffe RC: Implantation in the baboon: Endometrial responses. Semin Reprod Endocrinol 17: 257-265, 1999.

44. Vale W, Rivier C, Hsueh A, Campen C, Meunier H, Bicsak T, Vaughan J, Corrigan A, Bardin W, Sawchenko P, et al: Chemical and biological characterization of the inhibin family of protein hormones. Recent Prog Horm Res 44: 1-34, 1988.

45. Mylonas I, Jeschke U, Winkler L, Makovitzky J, Richter DU, Briese V and Friese K: Immunohistochemical expression of inhibin-alpha in human endometrium and the in vitro secretion of inhibin, estradiol and cortisol in cultured human endometrial glandular cells. Arch Gynecol Obstet 268: 142-150, 2003.

46. Mylonas I, Winkler L, Jeschke U, Briese V and Friese K: Investigations on isolation, purification and cultivation of human endometrial cells and on the in vitro inhibin expression in glandular epithelial cells. Zentralbl Gynakol 125: 415-423, 2003 (In German). 